\title{
REPRESENTASI FEMINISME EKSISTENSIALIS TOKOH WANITA DALAM FILM THE GREAT WALL
}

\author{
Rizky Wardhani, Zuriyati, Ninuk Lustyantie \\ Universitas Negeri Jakarta (UNJ), Indonesia \\ Email: rizkywardhani@.unj.ac.id, zuriyati@unj.ac.id,ninuk.lustyantie@unj.ac.id
}

\begin{abstract}
Abstrak
Penelitian ini mengangkat tema kajian feminisme dalam seni peran terutama pada perfilman. Tokoh wanita yang terdapat di film ini digambarkan sebagai seorang tokoh wanita yang kuat dan berjiwa pemimpin. Tokoh wanita ini eksis di antara dominasi para kaum pria seperti biasanya. Seorang tokoh wanita biasanya digambarkan dengan peran yang feminine, tetapi dalam film ini peran yang ditampilkan sangat bertolak belakang. Dari peran tokoh ini wanita dalam film The Great Wall ini memunculkan sisi Feminisme Eksistensialis yaitu wanita digambarkan sebagai seorang sosok yang memiliki tingkat kemandirian, cara berpikir yang tidak tergantung oleh kaum pria. Penelitian ini menggunakan penelitian deskriptif kualitatif dengan menggunakan strategi yang dikemukakan oleh Simone de Beauvoir, yaitu bagaimana perempuan memaknai diri, yaitu: 1) bekerja dan menentukan nasib; 2) bergabung dengan kelompok intelektual, berpikir, melihat, dan mendefinisikan untuk membawa perubahan bagi perempuan; 3) bekerja dan mencapai transformasi sosial dalam masyarakat; dan 4) menolak menginternalisasi bahwa wanita dibawah laki-laki. Penelitian ini menunjukkan bahwa sisi emosional dari seorang wanita tidak dapat mengubah tokoh seorang wanita dalam menghadapi masalah, hal ini terlihat dari alur cerita yang diberikan pada film yang bergenre kolosal ini.
\end{abstract}

Kata Kunci: representasi; feminisme eksistensialis; Simone De Beauvoir; The Great Wall

\section{Abstract}

This research aims at the theme of the study of feminism in acting, especially in film. The female figure in this film is described as a strong and spirited female figure. This female figure exists among the domination of men as usual. A female figure is usually portrayed in a feminine role, but in this film, the roles shown are very different. From the role of this female character in this film "The Great Wall", emerges the Existentialist Feminism side, for example, that women are described as a figure who has a level of independence, a way of thinking that is not dependent on men. This study uses descriptive qualitative research using the strategy proposed by Simone de Beauvoir, how women interpret themselves, like 1) work and determine fate; 2) join intellectual groups, think, see, and define to bring about change for women; 3) work and achieve social transformation in society, and 4) refuse to internalize that women are below men. This study shows that the emotional side of a woman cannot change the character of a woman in dealing with problems, this can be seen from the storyline given in this colossal genre film.

$\begin{array}{ll}\text { How to cite: } & \text { Wardhani,R., Zuriyati, Lustyantie,N., (2021) Representasi Feminisme Eksistensialis Tokoh Wanita } \\ & \text { dalam Film The Great Wall, Syntax Idea, 3(12), https:// doi.org/10.36418/syntax-idea.v3i12.1665 } \\ \text { E-ISSN: } & \text { 2684-883X } \\ \text { Published by: } & \text { Ridwan Institute }\end{array}$


Rizky Wardhani, Zuriyati, Ninuk Lustyantie

Keywords: representation; existentialist feminism;Simone De Beauvoir; The Great Wall

Received: 2021-11-22; Accepted: 2021-12-05; Published: 2021-12-20

\section{Pendahuluan}

Kajian dalam film sangat menarik untuk dikupas. Banyak film mengangkat sosok seorang wanita sebagai objek utama dalam suatu film dan menjadikan peran utama sebagai dari permasalahan. Studi tentang wanita selalu menarik untuk dibicarakan. Sosok seorang wanita yang telah kita kenal sejak kita lahir menjadi satu panutan dalam kehidupan. Tanpa sosok seorang wanita, seseorang tidak akan dapat melewati fase dalam kehidupannya. Ketika membicarakan suatu film kita akan berbicara tentang budaya suatu bangsa. Mengapa demikian? Latar belakang suatu film didasari oleh kajian budaya suatu bangsa tersebut (Fajriah, 2011).

Film dengan genre feminisme sudah banyak dibahas oleh para sineas terkemuka. Feminisme terkadang ditunjukkan dengan sosok yang indah, cantik dan dijaga secara objek yang lemah sehingga harus dilindungi. Sebenarnya bagaimana kita memandang sebuah kajian wanita terkait dengan studi-studi yang pernah ada sebelumnya? Hal ini menjadi suatu topik yang menarik untuk dibahas. Mengapa demikian? Jika kita melihat sosok seorang wanita, pertama kali yang muncul dalam benak dan pikiran seseorang tentu sosok yang cantik, anggun, dan menarik, pernahkah kita mengeluarkan pengandaian dengan kata wanita yang pertama kali terucap adalah tangguh, berani, dan kuat? Hal ini biasanya akan terkait dengan perumpamaan seorang pria (Sos, 2018).

Bagian terbesar dari kajian budaya terpusat pada representasi, yaitu bagaimana dunia ini dikonstruksi dan direpresentasikan secara sosial kepada kita dan oleh kita. Jadi unsur utama kajian budaya adalah kebudayaan sebagai praktik pemaknaan representasi. Ini berarti bahwa kajian budaya mengharuskan eksplorasi pembentukan makna tekstual dan cara dihasilkannya pada beragam konteks. Representasi dan makna budaya memiliki materi tertentu dan melekat pada bunyi, prasasti objek, citra, buku, majlah dan program televisi. Mereka diproduksi, ditampilkan dan digunakan dan dipahami dalam konteks sosial (Purnomo, 2010).

Pada kajian budaya ini unsur feminin biasanya terkait erat dengan tema-tema budaya. Sebagian besar dipopulerkan lewat media yang diproduksi oleh para pengembang dan para kapitalis, Pada konteks budaya populer juga terdapat konteks industri modern dan budaya media, representasi oleh perusahaan karena terdorong oleh motif mencari laba. Konsekuensinya yaitu mengaitkan representasi wanita pada produksi budaya. Jika dikaitkan dengan perkemba, ngan feminsme dari awal munculnya aliran feminsme maka dapat dilihat budaya representasi wanita sangat menonjol, karena wanita sebelumnya sebagai objek (Adhtiya, 2015).

Masyarakat di era modern ini sangat senang jika diberikan suatu informasi dalam bentuk film sebagai tontonan dan bahan pembelajaran yang berharga terutama dari sisi pengalaman yang dapat dipetik. Konsep budaya populer juga meluas ke beberapa film tentang feminisme, seperti: (Soderbergh, Roberts, Finney, \& Eckhart, 2000), 
(Fitzgerald, 2018), (DeLancey, 1994), (Johnson \& Lyman, 2020), versi animasi selalu ditampilkan seorang putri yang cantik seperti Frozen dan Brave produksi Disney. Di Indonesia juga hangat diperbincangkan film dengan tema feminine, seperti R.A. Kartini, Arisan, dan juga Caubakan. Sedangkan di Asia Timur juga ada beberapa film dan drama, seperti The Curse of Golden Flower, Hero, Impian Loteng Merah/Hong Lou Meng, The Great Wall (Cina), MrQueen (Korea Selatan).

Dari film yang telah dijelaskan di atas, beberapa karakter wanita memiliki sifat feminine yang berbeda. Wanita memiliki sifat-sifat yang berbeda dan jauh lebih mandiri dengan mengutamakan kecerdasan intelektual yang tinggi. Konsep budaya lebih diartikan secara politis ketimbang estetis, Storey beranggapan budaya yang dipakai dalam cultural studies bukanlah konsep budaya seperti yang didefinisikan dalam kajian lain sebagai objek keadiluhungan estetis dengan seni tinggi atau sebuah proses perkembangan estetika, intelektual dan spritual, melainkan budaya teks dan praktik hidup sehari-hari (Storey, 2018).

Salah satu film yang menunujukkan sifat kemandirian serta intelektual yang tinggi ini muncul dalam tokoh utama wanita bernama Komandan Lin pada film The Great Wall, yang disutradarai oleh Zhang Yimou. Sutradara terkenal ini sudah menghasilkan banyak film yang bermutu dan memenangkan penghargaan di dalam dan juga luar negeri. Film ini juga merupakan kolaborasi antara para sineas dari negeri Tiongkok dan juga Amerika Serikat terutama perfilman Hollywood. Film ini sebenarnya merupakan film fiksi kolosal dengan mengambil latar belakang masa kerajaan dengan para prajurit yang menjaga banteng terluar di seluruh penjuru negeri Tiongkok terutama ketika ada serangan musuh yang datang. Cerita yang disajikan juga tidak membosankan karena menampilkan efek sinamtografi yang mumpuni. Tokoh tamu dari bintang film Hollywood pun dapat membuat film ini lebih hidup lagi terutama dimainkan oleh Matt Damon, Pedro Pascal dan Willem Dafoe. Dari pihak Tiongkok dan juga artis Hongkong pun banyak turut berperan dalam film ini, seperti Andy Lau, Jing Tian, Zhang Hanyu, Eddie Peng, dan masih banyak lainnya. Keunikan dari film ini yaitu cerita yang menghadirkan kisah mitos fiksi yang menghadirkan hewan Tao Tei sebagai peran antagonis. Keunikan cerita lain yaitu ada nilai budaya dan bahasa yang ingin ditampilkan oleh sutradara dalam film ini. Hal terjadi ketika Pastor Ballard telah lama tinggal di salah satu benteng Great Wall dan dapat berbicara bahasa Mandarin dengan fasih dengan seluruh penghuni, prajurit banteng. Keunikan lain adanya peran sekelompok wanita yang menjadi pasukan khusus pada salah satu tim prajurit. Pasukan khusus ini terdiri hanya kaum wanita pemberani yang telah dididik dari lahir sebagai pasukan khusus tombak.

Penelitian relevan yang terkait dengan film The Great Wall pernah dilakukan oleh (Wibisono, Tjahjo, \& Wahjudianata, 2017) dari Universitas Kristen Petra Surabaya, dengan menitikberatkan kepada orientalisme pada film The Great Wall, sisi ketimuran yang dimunculkan pada film tersebut dikaji dengan menggunakan metode semiotika televisi John Fiske melalui 3 level, yaitu Level realitas, level representasi, dan level ideologi. Hasil ini yang didapat berdasarkan kode-kode tersebut, terdapat konsep 
orientalisme yang dikemas dengan gaya barat dalam penggambaran karakter dan budaya timur melalui film ini.

Penelitian sebelumnya hanya mengungkapkan sisi orientalisme pada film, tetapi belum membahas mengenai sisi peran pada pemain film. Oleh karena itu dengan adanya peran wanita pada film ini, peneliti tertarik untuk mengupas tentang peran tokoh wanita dalam film tersebut, karena mempunyai ciri khas yang pada pengembangan budaya feminisme yaitu peran wanita bukan sebagai objek tetapi subjek utama dan memegang kendali di antara para pemain para pria, bahkan melampaui dugaan akan memimpin sebagai prajurit perang. Peran wanita pada tokoh ini yaitu Komandan Lin ini yang akan dikaji menggunakan strategi yang dikemukakan oleh Simone de Beauvoir, yaitu bagaimana perempuan memaknai diri, yaitu: 1) bekerja dan menentukan nasib; 2) bergabung dengan kelompok intelektual, berpikir, melihat, dan mendefinisikan untuk membawa perubahan bagi perempuan; 3) bekerja dan mencapai transformasi sosial dalam masyarakat; dan 4) menolak menginternalisasi bahwa wanita dibawah laki-laki (Carter, 2006).

\section{Metode Penelitian}

Penelitian ini menggunakan pendekatan kualitatif, dan metode yang digunakan adalah strategi yang dipakai pada pendapat Beauvoir, yaitu : 1) bekerja dan menentukan nasib; 2) bergabung dengan kelompok intelektual, berpikir, melihat, dan mendefinisikan untuk membawa perubahan bagi perempuan; 3) bekerja dan mencapai transformasi sosial dalam masyarakat; dan 4) menolak menginternalisasi bahwa wanita dibawah lakilaki (Eda, 2020).

Penelitian ini menggunakan teknik pengumpulan data dokumentasi. Pengumpulan data dokumentasi adalah pengumpulan data yan diperoleh berupa dokumen, teks, karya seni atau gambar (Nilamsari, 2014). Data yang diperoleh peneliti adalah hasil scene screenshoot (SS)/capture dari film. Film dapat ditonton streaming melalui website Iqiyi, YouTube. Jika beberapa SS terlalu susah diambil maka peneliti duga akan mengunduh menggunakan aplikasi gratis www.savefromnet.co. Setelah itu gambar yang diambil dikelompokkan berdasarkan kemunculuan peran yang muncul, terutama peran wanita yaitu Komandan Lin sebagai ketua prajurit batalion benteng utara Great Wall dan memimpin seluruh pasukan untuk membasmi Tao Tei.

\section{Hasil dan Pembahasan}

Peneliti menemukan data bahwa film ini didominasi oleh peran pria. Diawali dengan dua tokoh utama pada film ini yaitu William dan Pero yang dikenal sebagai tentara bayaran dan rela melakukan apapun demi uang untuk bertahan hidup. Hal ini yang membuat kedua sahabat ini berkelana jauh dari benua Eropa menuju benua Asia untuk menemukan sesuatu yang dapat dijual dengan harga tinggi di Eropa. Kedua orang ini sebenarnya memimpin dan membawa 20 puluh orang dalam perjalanan ke benua Asia. Konon di benua Asia telah ditemukan bubuk mesiu yang merupakan senjata yang 
sangat mematikan. Tetapi di tengah perjalanan, pasukan mereka diserang oleh makhluk aneh dan misterius dengan darah berwarna hijau dan kebiru-biruan.

Tanpa disadari oleh keduanya, makhluk aneh yang mereka serang itu bernama TaoTei, suatu makhluk yang berasal dari meteor dan akan bangkit setiap 60 tahun untuk memusnahkan bumi dan menyebarkan kejahatan. William dan Pero kehilangan seluruh pasukannya tetapi mereka berhasil membunuh salah satu makhluk Tao Tei, dan membawa salah satu tangannya dan melanjutkan perjalanan. Setelah berjalan di tengah gurun, akhirnya mereka sampai di perbatasan benteng yang tinggi dan besar dan dikepung oleh tentara untuk ditangkap dan menyerahkan seluruh barang bawaannya.

Film The Great Wall, memperlihatkan tokoh William dan temannya Pero sebagai dua orang sahabat yang mempunyai misi menjadi kaya dengan penemuannya, teapi di dalam pencarian hartanya tersebut menemukan suatu pengalaman untuk bertarung bersama dengan pasukan dari Tiongkok dan dibawah pimpinan seoerang wanita yaitu Komandan Lin.

Tokoh dari Komandan Lin inilah yang akan digambarkan melalui penggamaran dari sifat dan teori Feminisme Eksistensialis. Tokoh ini muncul di antara dominasi peran para pria yang ada pada mayoritas di pasukan benteng utara tersebut. Oleh karena itu peneliti akan menelaah 4 strategi yang dipakai pada pendapat (Carter, 2006) yaitu : 1) bekerja dan menentukan nasib; 2) bergabung dengan kelompok intelektual, berpikir, melihat, dan mendefinisikan untuk membawa perubahan bagi perempuan; 3) bekerja dan mencapai transformasi sosial dalam masyarakat; dan 4) menolak menginternalisasi bahwa wanita dibawah laki-laki.

Telaah dari strategi ini akan dilihat pada adegan-adegan yang akan ditampilkan pada film ini.

\section{Wanita bekerja dan dan menentukan nasib.}

Pada bagian ini terdapat beberapa adegan yang menyiratkan bahwa Komandan Lin mendapat kehormatan untuk memimpin pasukan khusus wanita di antara pasukan yang mayoritas terdiri dari dominasi pria. Hal ini ditunjukkan pada adegan berikut ini :

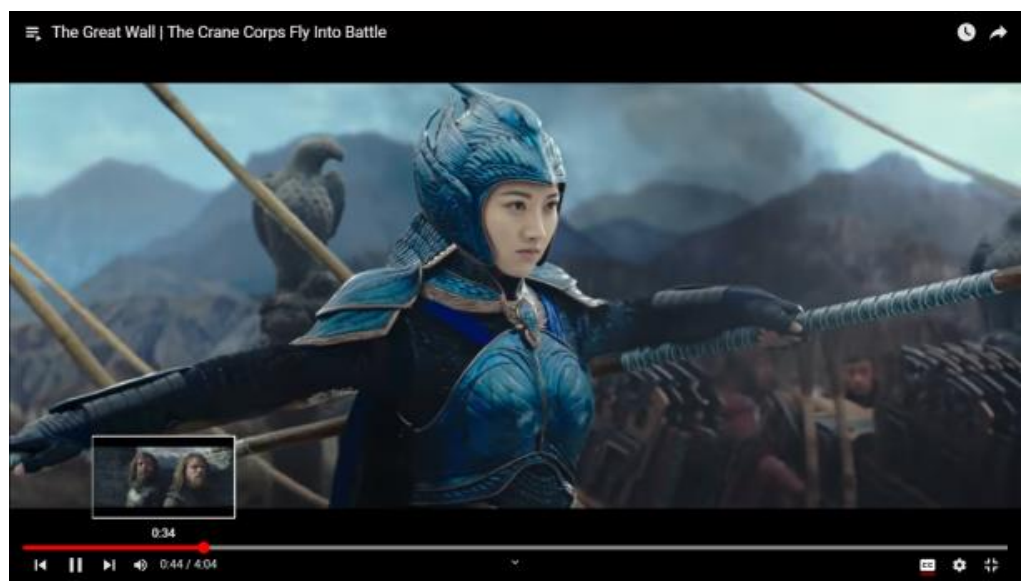




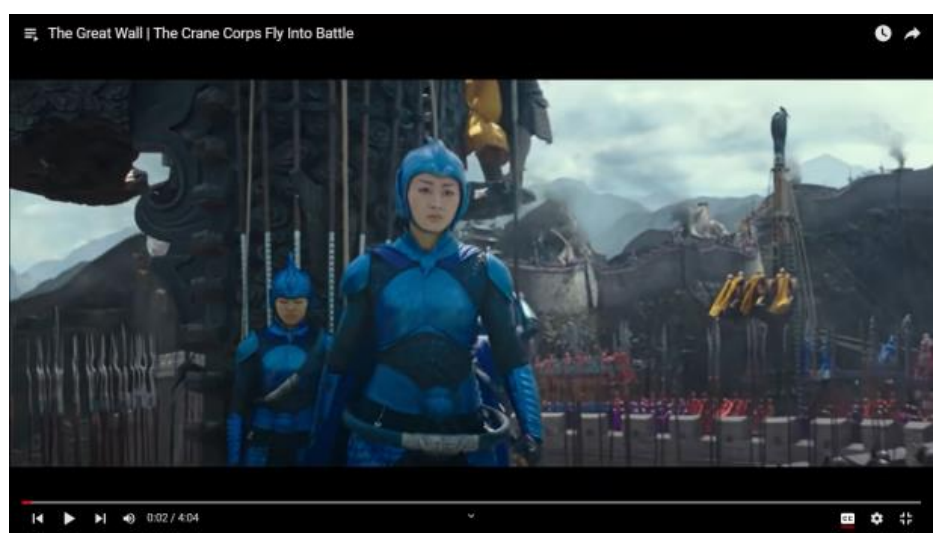

Gambar 1 dan 2

Komandan Lin pada peperangan melawan TaoTei (www.youtube.com)

Di adegan lain Komandan Lin dan pasukan wanita menunjukkan keahliannya dalam berperang melawan TaoTei dengan menggunakan tombak dan badan diikat dengan tali dan dijatuhkan dari ketinggian tembok benteng barat laut. Hal ini ditunjukkan pada adegan berikut ini :
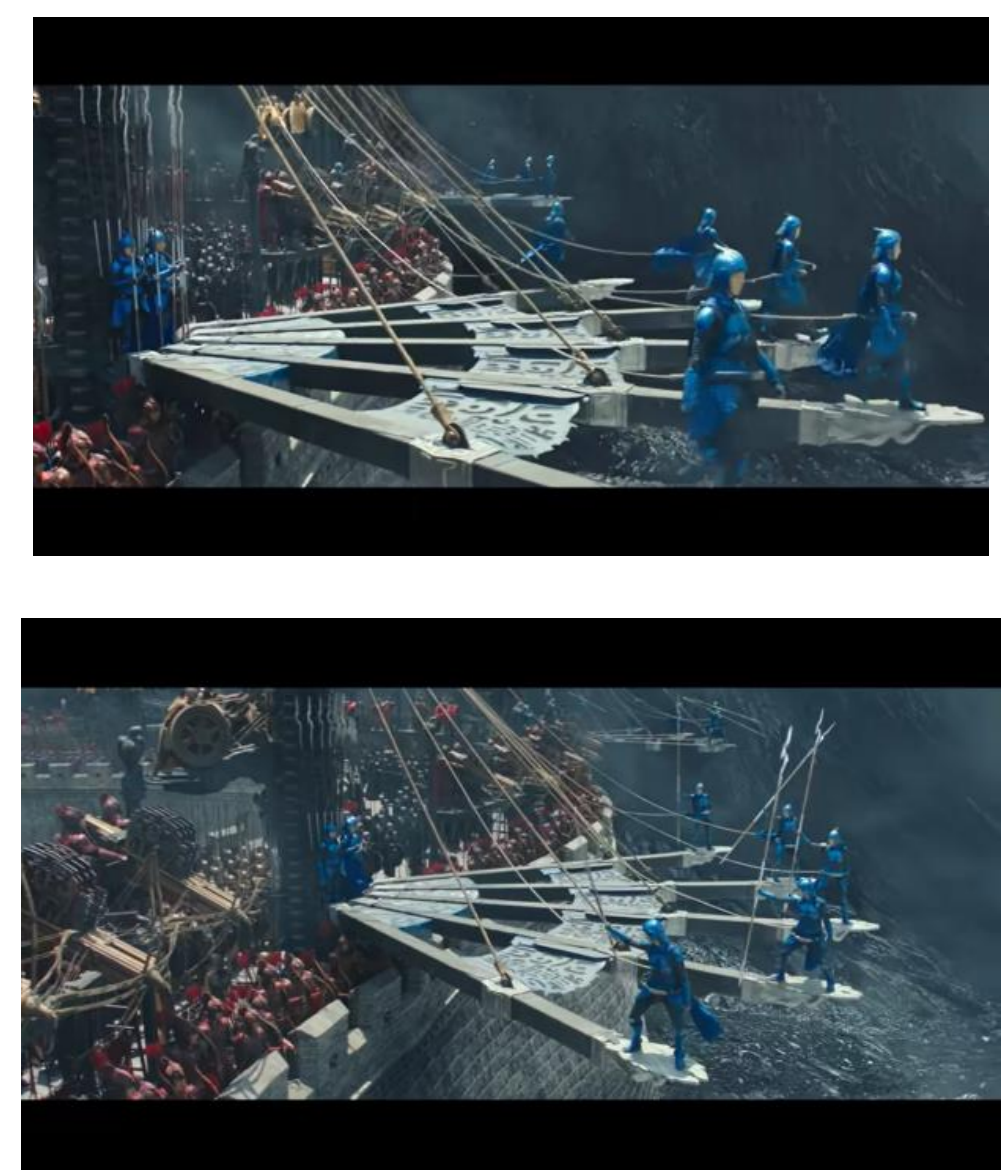

Gambar 3 dan 4

Persiapan pasukan tali dan tombak melawan TaoTei (www.youtube.com) 
Dari adegan ini dapat terlihat bahwa perubahan yang dihasilkan mencerminkan bahwa peran wanita pada pasukan ini sangat besar. Pasukan tali dan tombak ini terpilih karena memang dikhususkan untuk kaum wanita, mengapa demikian ? Pada pasukan tali ini, dibutuhkan kecekatan dan keterampilan seorang wanita yang memiliki tubuh yang ringan karena harus ada koordinasi dengan tim pengerek tali untuk kembali mengambil tombak di atas benteng setelah diturunkan ke bawah untuk membunuh makhluk TaoTei. Dalam hal ini, menjadi seorang wanita sangat diuntungkan karena memiliki tubuh yang lebih ringan dibandingkan dengan kaum pria, hal perubahan yang dihasilkan ini menunjukkan gerakan feminis telah menyentuh banyak aspek kehidupan dengan cara yang positif dengan adanya dasar kesetaraan dan keadilan dalam hal pekerjaan.

Di akhir adegan film ini, pekerjaan Komandan Lin juga menunjukkan naiknya strata sosial bagi seoerang pemimpin wanita sebagai jenderal dari benteng barat laut. Komandan Lin digambarkan sebagai seorang sosok wanita yang penuh wibawa hal ini terlihat dari pakaian megah yang dikenakannya.

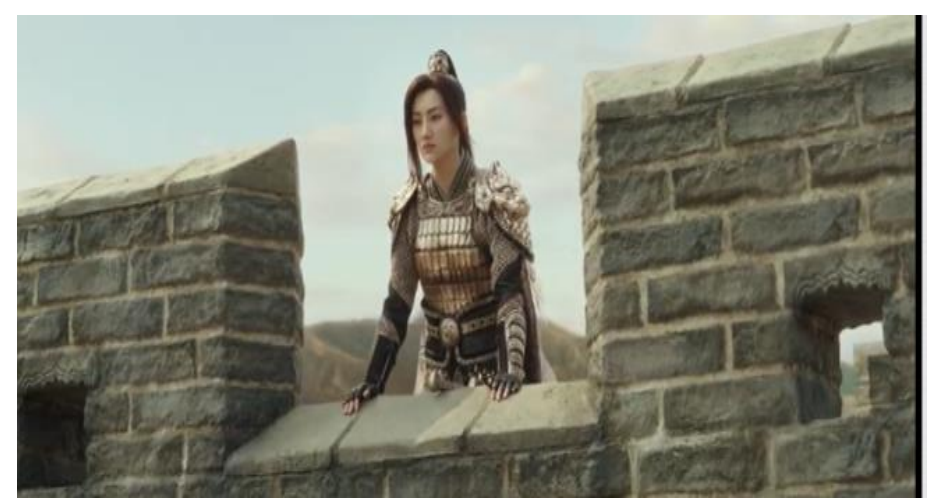

Gambar 5

Komandan Lin sebagai Jenderal Benteng Barat Laut (www.youtube.com)

\section{Bergabung dengan kelompok intelektual membawa perubahan bagi kaum wanita}

Pada bagian ini Komandan Lin, sebagai wanita memiliki jabatan yang tinggi sebagai salah satu komandan wanita di pasukan benteng barat laut. Beberapa adegan pada film ini menunjukkan adanya peran wanita yang menunjukkan sosok feminis tapi menonjol dan berada pada dominasi pria yang dapat dikatakan berperan dari sisi feminis eksistensialis, hal ini terlihat dari keterlibatannya dalam beberapa adegan yang menunjukkan Komandan Lin sebagai kaum intelektual dan pendapatnya sangat diperhitungkan. Hal ini ditunjukkan pada adegan berikut ini: 

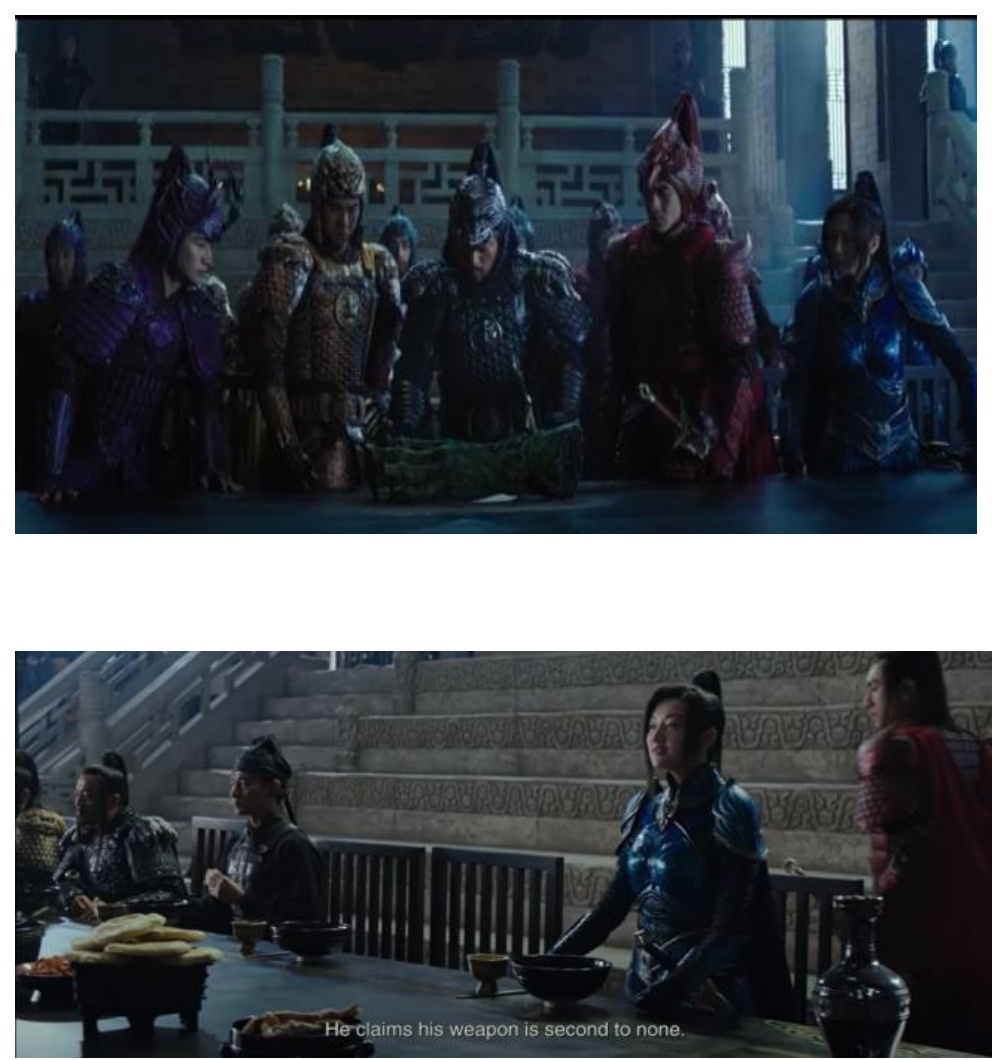

\section{Gambar 6 dan 7}

\section{Kedatangan Willian dan Pero membawa tangan Tao Tei} (www.youtube.com)

Pada gambar 6, terlihat jelas bahwa Komandan Lin hanya satu-satunya wanita yang memegang peranan penting sebagai salah satu komandan di benteng barat laut, selebihnya komandan dipegang oleh dominasi pria. Gambar ini memperlihatkan para komandan sedang memeriksa bagian tangan yang dibawa oleh William dan merasa aneh bahwa dia dapat membunuh makhluk ini. Kemudian pada Gambar 7, menunjukkan bahwa Komandan Lin memiliki pendapat yang sangat diperhitungkan, hal ini terlihat dari pendapatnya ketika mengatakan bahwa Willian dan Pero hanya ingin datang mengambil keuntungan dari benteng barat laut dan mempertanyakan mana mungkin kalau kedua orang itu dapat membunuh makhluk itu tanpa senjata.

Di bagian lainnya, sosok feminis eksistensialis ini ditunjukkan oleh Komandan Lin pada adegan ketika ia memimpin persiapan peperangan dengan makhluk Tao Tei. Hal ini terlihat pada adegan berikut ini: 

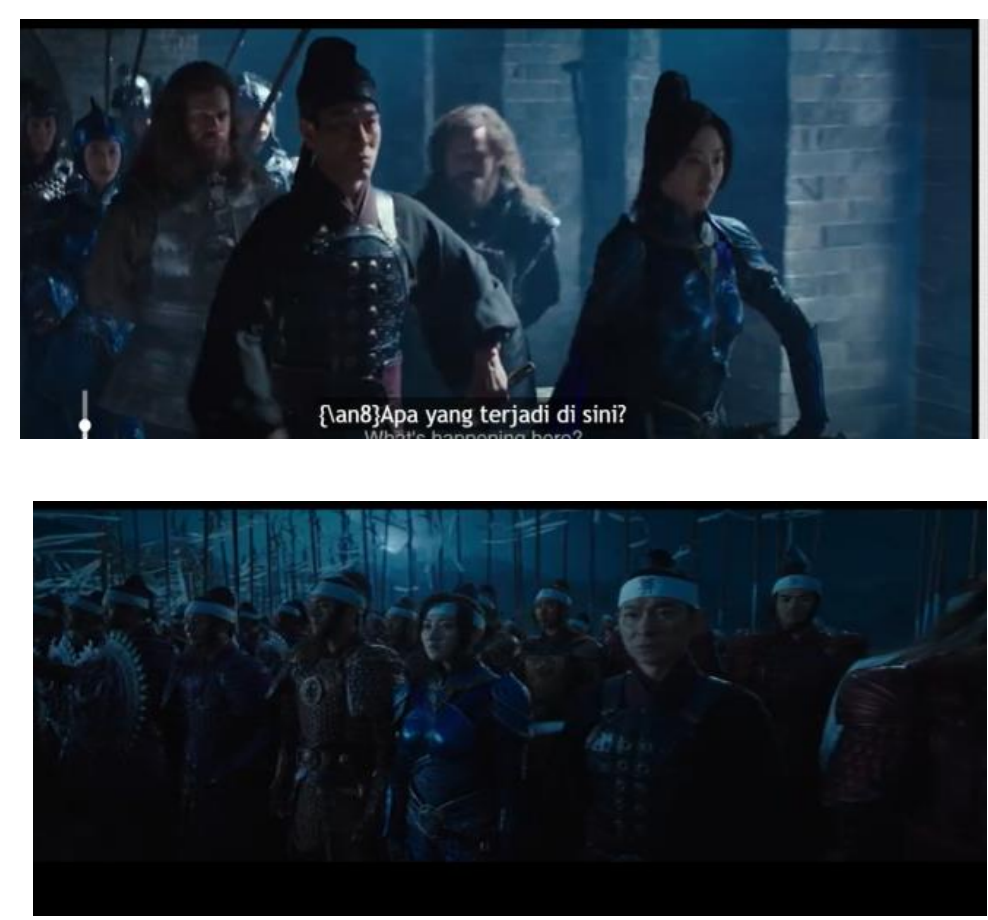

Gambar 8 dan 9

Komandan Lin memimpin pasukan dan pelepasan jenazah Jenderal Shao (www.youtube.com)

Adegan tersebut menunjukkan bahwa Komandan Lin dapat mempimpin pasukan dan berada di antara kaum pria sebagai satu-satunya pemimpin wanita. Selanjutnya pada adegan pelepasan jenazah Jenderal Shao pun, Komandan Lin berada di antara para pemimpin pria. Hal ini menunjukkan dirinya sangat eksis dan diperhitungkan pada jajaran pemimpin di pasukan benteng barat laut.

\section{Bekerja dan mencapai transformasi sosial dalam masyarakat}

Strategi feminis eksistensialis dari Beauvoir selanjutnya yaitu pada tahap transformasi sosial dalam masyarakat. Hal ini terlihat dari beberapa adegan pada film ini yaitu mendapat pengakuan dari Willian dan Pero yang sedang terikat dan merasakan sebuah koordinasi yang luar biasa di antara para pasukan. Pasukan dengan berbagai kode warna, yaitu pasukan berpakaian warna hitam sebagai prajurit, pasukan berpakaian warna merah sebagai pemanah, pasukan berpakaian warna ungu sebagai penyerang jarak dekat, pasukan berwarna kuning sebagai pengerek tali, dan terakhir adalah pasukan berwarna biru yang keseluruhan anggotanya terdiri dari kaum wanita. Hal ini membuat William dan Pero merasa aneh. Terlihat pada adegan di bawah ini bahwa para wanita yang berada di pasukan biru ini telah mencapai satu transformasi sosial dalam masyarakat. 

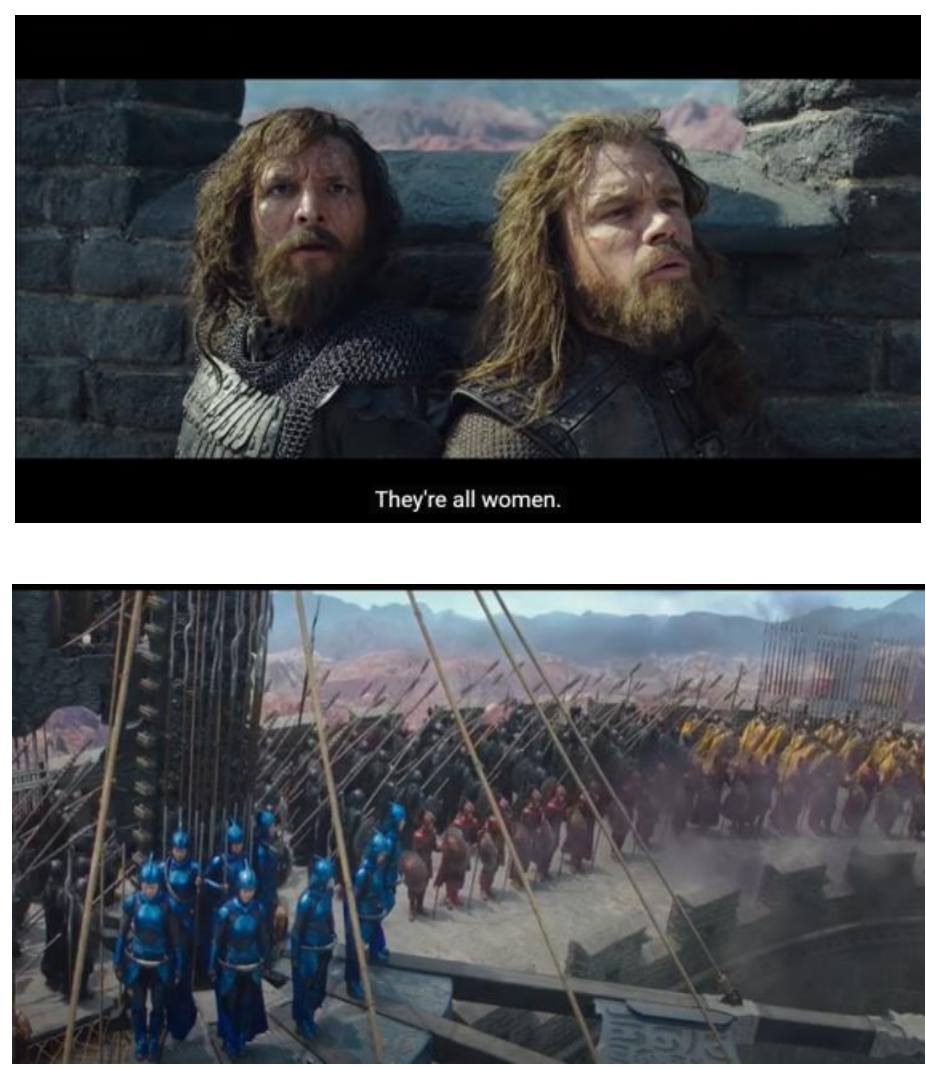

Gambar 10 dan 11

William dan Pero merasa kaget dengan pasukan benteng barat laut dan pasukan Wanita (www.youtube.com)

Selanjutnya transformasi sosial dalam masyarakat yang ditampilkan pada film ini terhadap tokoh utama wanita yaitu Komandan Lin mencapai satu posisi sebagai Jenderal Lin yaitu peranan terpenting pada benteng barat laut. Hal ini terjadi ketika Jenderal Shao wafat setelah bertarung dengan makhluk TaoTei dan memberikan mandat agar Komandan Lin menggantikan dirinya untuk memimpin seluruh pasukan dari benteng barat laut. Hal ini tergambar pada adegan berikut ini: 

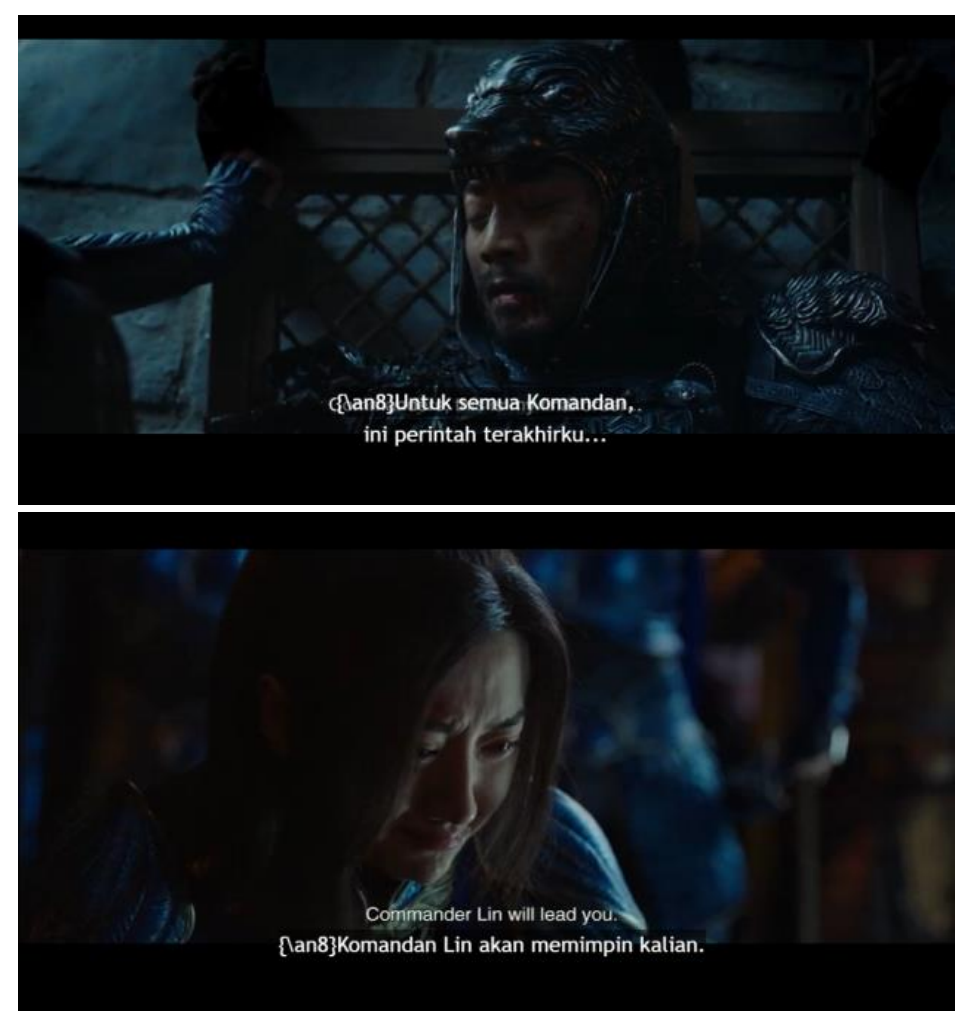

\section{Gambar 12 dan 13 \\ Detik-detik Jenderal Shao memberikan mandat kepada Komandan Lin (www.youtube.com)}

Transformasi sosial dalam masyarakat juga ditunjukkan oleh Jenderal Lin ketika Pero dan Ballard melarikan diri dengan membawa senjata yang seharusnya dirahasiakan dari dunia luar, karena senjata ini sangat mematikan yaitu bubuk mesiu salah satu dari 4 penemuan terbesar bangsa Tiongkok yang dapat mengubah dunia. Oleh karena itu mereka merahasiakan keberadaan bubuk mesiu ini. Pada adegan interviu dengan William yang akhirnya tertangkap dan disangka sengaja melepaskan Pero dan Ballard, dapat terlihat karakter feminis eksistensialis pada diri jenderal Lin. Kata-kata tegas Jenderal Lin ketika menginterogasi William sangat mengintimidasi hingga akhirnya William diselamatkan oleh salah satu prajurit yang menyaksikan bahwa William sebenarnya tidak ingin melarikan diri, tetapi bahkan ingin mencegah Pero dan Ballard untuk membawa bubuk mesiu keluar dari benteng. Hal ini tergambar pada adegan di bawah ini: 


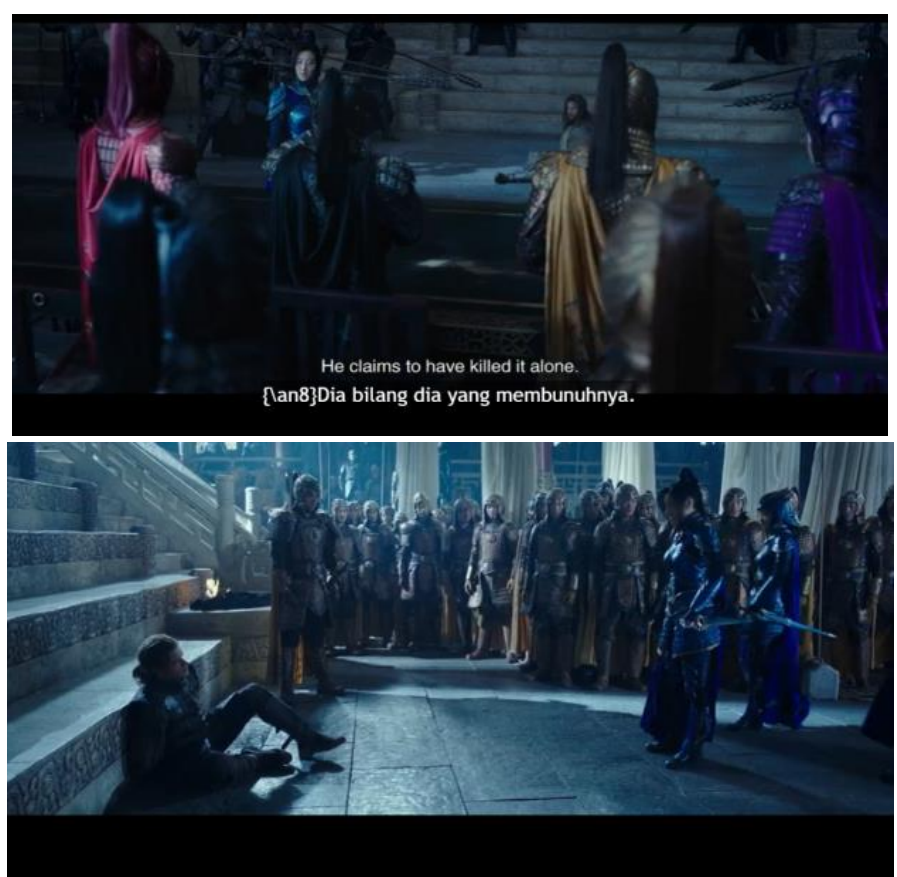

Gambar 14 dan 15

Jenderal Lin Menginterogasi William

(www.youtube.com)

Pada adegan terakhir sebelum perpisahan, Willian juga menegaskan keberadaan Jenderal Lin sebagai salah seorang Jenderal dari benteng barat laut yang telah menyelamatkan negara dan dunia. Hal ini menunjukkan bahwa Jenderal Lin sebagai seorang wanita memiliki status strata sosial pada tingkatan tinggi di masyarakat. Hal ini dapat terlihat pada adegan ini :

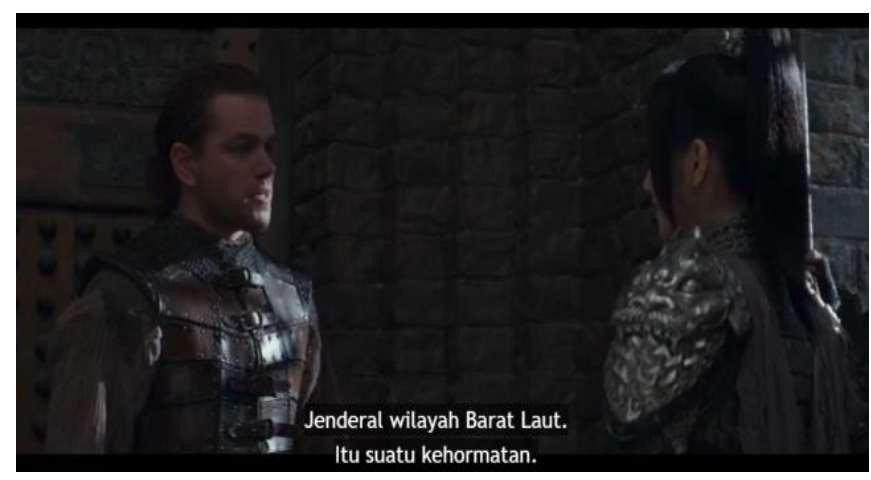

Gambar 16

Pernyataan William memberikan apresiasi kepada Jenderal Wilayah Barat laut (www.youtube.com)

\section{Menolak menginternalisasi bahwa wanita dibawah laki-laki}

Pembahasan selanjutnya yaitu menjelaskan tokoh wanita pada film ini menunjukkan sangat eksis dan berada di atas kaum pria. Hal ini ditunjukkan dalam beberapa adegan dan juga dialog yang terjadi di atara para tokoh. Salah satu adegan yaitu ketika Komandan Lin mengajak Willian menunjukkan bagaimana berlatih 
sebagai pasukan tali dan tombak. Komandan Lin menunjukkan bahwa dia harus berjalan dengan percaya diri melalui titian balok dengan keseimbangan, lalu menangkap tombak yang diberikan oleh pasukan kuning pengerek atau sesama rekan di pasukan biru dan menerjunkan diri untuk membidik musuh di medan pertempuran bagian bawah. Pada adegan ini Komandan Lin memandang sebelah mata kepada William bahwa ia tidak akan mampu untuk melakukannya, Komandan Lin mengatakan, "Hal ini seharusnya para pria yang mengajarkan kepada para wanita, apakah kamu tahu apa yang saya pikirkan? Saya rasa anda akan takut jika melakukan hal ini." Komandan Lin mengatakn hal ini dengan nada meremehkan. Hal ini menandakan bahwa tokoh wanita dalam peran ini memiliki kepercayaan diri yang sangat tinggi untuk melakukan hal yang sangat mustahil dilakukan oleh sebagian orang. Selain itu ditunjang oleh dialog yang diucapkan oleh para pengawal Komandan Lin yang mengatakan, "Para pria sangat berat, dan para tim tidak akan mampu untuk menariknya." Adegan ini dapat terlihat dalam rekam gambar berikut ini:
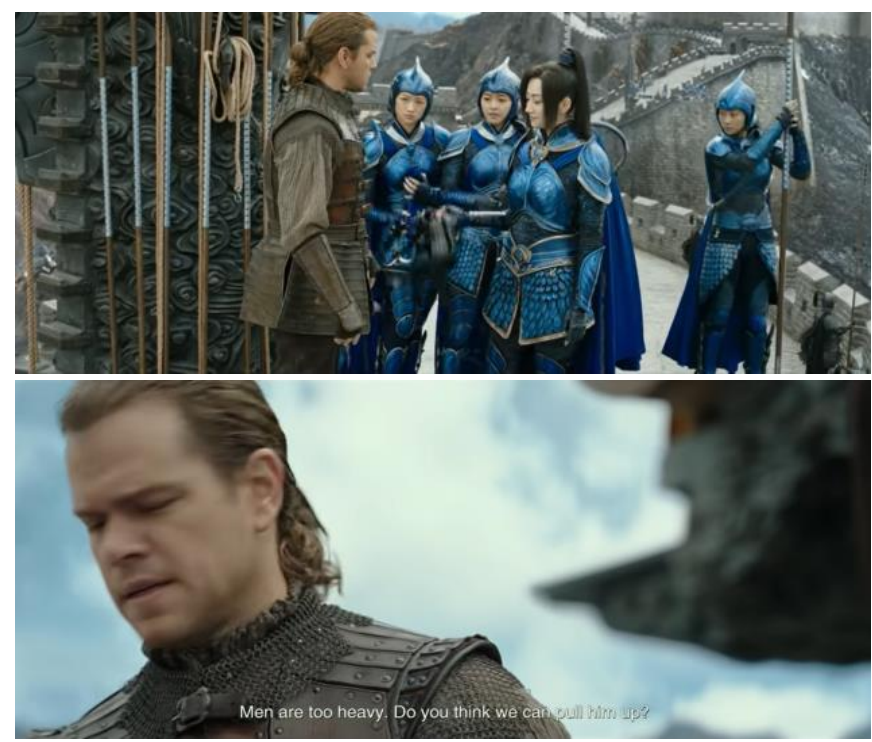

Gambar 17 dan 18

William mencoba untuk melakukan gerakan lompat dan terjun dari benteng (www.youtube.com)

Hal lain yang dilakukan oleh Jenderal Lin yang menunjukkan rasa percaya dirinya yaitu ketika ia mengatakan dengan percaya diri bahwa ia mempercayai William akan berhasil membidik senjata ke ratu makhluk TaoTei. Jenderal Lin mengucapkan kata "xinren" yang berarti "percaya" 


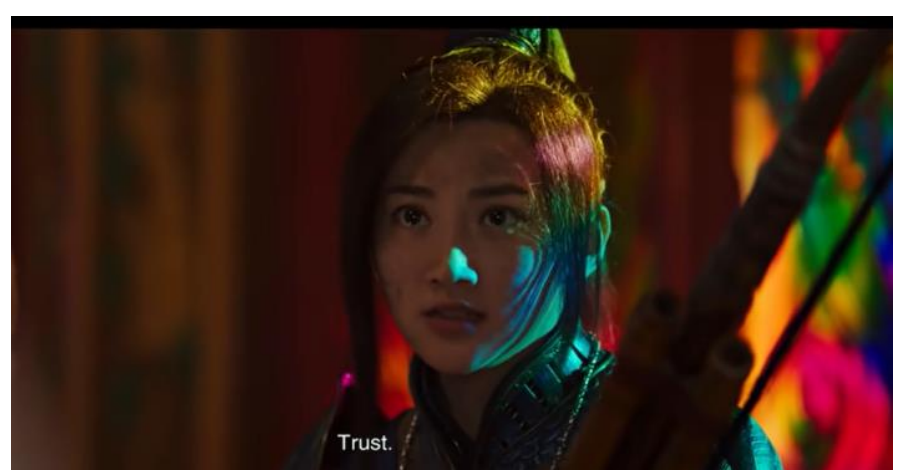

Gambar 19

Jenderal Lin mengucapkan kata"kepercayaan" kepada William (www.youtube.com)

Setelah mengatakan "percaya" kepada William, Jenderal Lin mengambil tali dan mengambil persiapan untuk terjun dari menara dan membidik senjata terakhir untuk membunuh ratu makhluk TaoTei hingga akhirnya makhluk itu mati. Kepercayaan diri yang dimiliki oleh Jenderal Lin terlihat dari cara dia mengayunkan tali dan bersiap untuk meloncat ke arena pertempuran, hal ini menunjukkan bahwa kepercayaan dirinya tidak tertekan oleh rasa takut dan tidak membebani William sebagai pria untuk melindungi dirinya di saat-saat genting. Adegan ini dapat dilihat dari rekam gambar berikut ini:

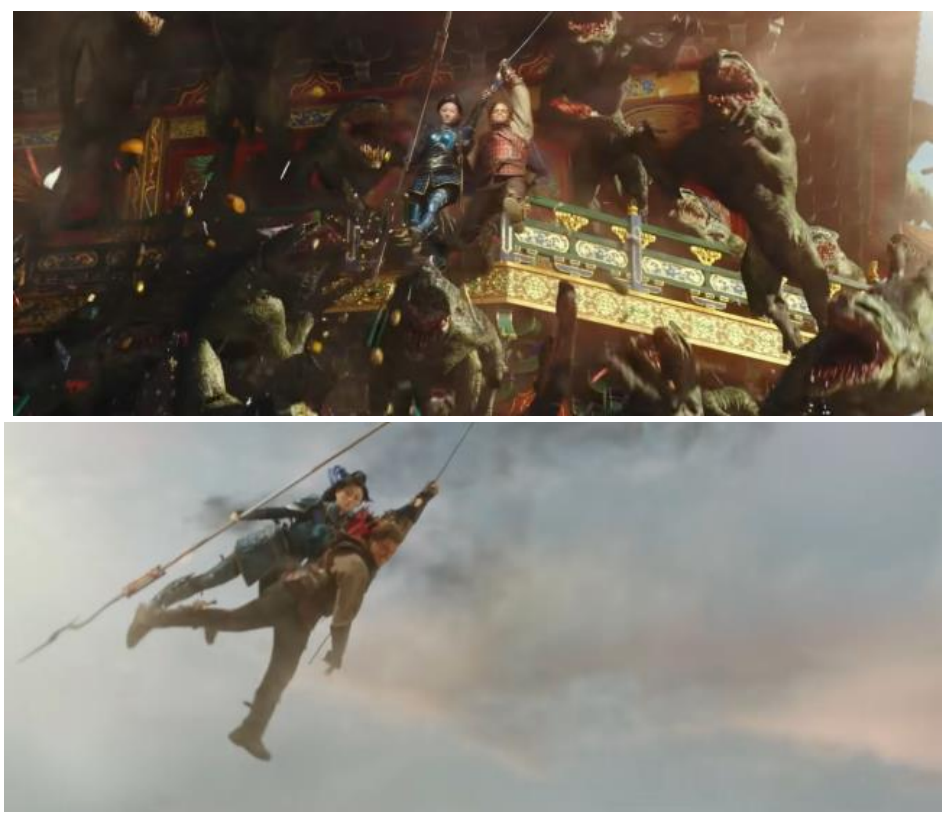

Gambar 20 dan 21

Jenderal Lin dan William berusaha membidik senjata ke ratu TaoTei (www.youtube.com) 


\section{Kesimpulan}

Berdasarkan analisis pada film, maka terlihat tokoh wanita yang ada pada film ini memiliki peran yang sangat penting, dan terlihat subjektivitas melalui filosofi yang ada. Eksistensialis menyatakan bahwa seseorang melalui tindakannya, kepercayaan dirinya, maka ia dapat menjadi sesuatu. Pada hal ini terlihat jelas bahwa tokoh utama pada film ini memiliki kendali mutlak atas apa yang ia lakukan. Dimulai dari pekerjaan yang ia pilih sebagai seorang prajurit dan telah berlatih dari kecil untuk mempersiapkan keadaan tempur yang akan dihadapinya. Sebagai seorang prajurit tokoh wanita yang bernama Lin ini sangat mendedikasikan dirinya berlatih hingga terampil dan memimpin pasukan yang seluruhnya bergender wanita. Hal ini menunjukkan bahwa keahlian dan kecerdasannya dapat menunjang hal kepemimpinannya. Selain itu kemampuan Jenderal Lin dalam berbahasa Inggris juga menjadi salah satu daya tarik utama di suatu lingkungan yang minoritas berbicara bahasa Inggris sehingga hal ini menambah keberadaan Jenderal Lin sebagai pemimpin utama.

Jenderal Lin sebagai salah satu intelektual juga tercermin pada cerita ini. Keberadaannya di tengah kaum pria sangat dominan dan memberikan sumbang saran dan taktik jitu dalam menaklukkan medan perang. Pada saat genting, Jenderal Lin memutuskan untuk menyelamatkan dunia dengan pergi ke pusat kerajaan untuk memburu makhluk TaoTei dan tidak mengkhawatirkan tawanan yang mungkin dapat membawa lari suatu kekayaan yang dapat dimiliki oleh bangsa barat yaitu bubuk mesiu. Hal ini ternyata membawa satu kepercayaan yang telah ditanam dan dimiliki oleh masing-masing prajurit untuk dapat saling percaya ketika berada di medan perang, saling melindungi satu sama lain. Sesama prajurit menganut "Xinren" atau "percaya", sehingga hal inilah yang menjadi landasan kemenangan dari pertarungan di pusat kerajaan ini.

Transformasi sosial dalam masyarakat juga terlihat pada film ini, ketika jenderal Shao wafat akhirnya digantikan oleh Komandan Lin yang akhirnya menjadi Jenderal dan memimpin seluruh pasukan yang didominasi oleh kaum pria. Hal ini menunjukkan feminis Eksistensialis pada film ini sangat terasa dan menunjukkan kelas sosial seorang wanita yang pada saat itu seharusnya berada di bawah pria menjadi sangat menonjol.

Semua representasi budaya wanita yang menunjukkan bahwa wanita berada di bawah pria tidak nampak pada film ini, bahkan cenderung pada dominasi wanita yang memiliki kekuatan dan perintah utama dalam memimpin sebuah pertarungan hingga akhirnya dapat memenangkannya. Jenderal Lin dapat membawa keberadaan wanita menjadi sangat utama dan disanjung karena telah menyelamatkan negara dari serangan makhluk TaoTei. 
Rizky Wardhani, Zuriyati, Ninuk Lustyantie

\section{BIBLIOGRAFI}

Adhtiya, Yuni. (2015). Keluarga di masyarakat Jawa dalam perspektif cultural studies. UIN Walisongo.Google Scholar

Carter, David. (2006). The pocket essential literary theory. Harpenden, UK: Pocket Essentials. Google Scholar

DeLancey, John O. L. (1994). Structural support of the urethra as it relates to stress urinary incontinence: the hammock hypothesis. American Journal of Obstetrics and Gynecology, 170(5), 1713-1723. Google Scholar

Eda, Friskha Dwita. (2020). Representasi Feminisme Dalam Film A Separation [Analisis Semiotika. Universitas Hasanuddin. Google Scholar

Fajriah, Nurlaelatul. (2011). Analisis semiotik film cin (T) a karya Sammaria Simanjuntak. Google Scholar

Fitzgerald, Barry W. (2018). Using superheroes such as Hawkeye, Wonder Woman and the Invisible Woman in the physics classroom. Physics Education, 53(3), 35032. Google Scholar

Johnson, Gregory C., \& Lyman, John M. (2020). Warming trends increasingly dominate global ocean. Nature Climate Change, 10(8), 757-761. Google Scholar

Nilamsari, Natalina. (2014). Memahami studi dokumen dalam penelitian kualitatif. WACANA: Jurnal Ilmiah Ilmu Komunikasi, 13(2), 177-181. Google Scholar

Purnomo, Mulyo Hadi. (2010). Menguak Budaya dalam Karya Sastra: Antara Kajian Sastra dan Budaya. Endogami: Jurnal Ilmiah Kajian Antropologi, 1(1), 75-82. Google Scholar

Soderbergh, Steven, Roberts, Julia, Finney, Albert, \& Eckhart, Aaron. (2000). Erin Brockovich. Columbia Tristar Home Video. Google Scholar

Sos, Sumekar Tanjung S. (2018). SEMIOTIKA BATAS (Analisis Terhadap Makna Batas dalam Film BATAS 2011 Karya Rudi Soedjarwo). Google Scholar

Storey, John. (2018). Cultural theory and popular culture: An introduction. Routledge. Google Scholar 
Representasi Feminisme Eksistensialis Tokoh Wanita dalam Film The Great Wall

Wibisono, Jill Arista, Tjahjo, Judy Djoko Wahjono, \& Wahjudianata, Megawati. (2017). Representasi Orientalisme Dalam Film The Great Wall. Scriptura, 7(1), 36-45. Google Scholar

\section{Copyright holder:}

Rizky Wardhani, Zuriyati, Ninuk Lustyantie (2021)

\section{First publication right:}

Syntax Idea

This article is licensed under:

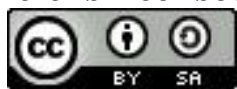

